\title{
ELECTROCOAGULATION METHOD FOR COLOUR REMOVAL IN TEA EFFLUENT: A CASE STUDY OF CHEMOMI TEA FACTORY IN RIFT VALLEY, KENYA
}

\author{
Justin K. Maghanga $^{1 *}$, Fred K. Segor ${ }^{1}$, Lazare Etiégni ${ }^{2}$ and John Lusweti ${ }^{1}$ \\ ${ }^{1}$ Moi University, Department of Chemistry and Biochemistry, P.O. Box 1125, Eldoret, Kenya \\ ${ }^{2}$ Moi University, Department of Forestry and Wood Science, P.O. Box 1125, Eldoret, Kenya
}

(Received September 26, 2008; revised April 26, 2009)

\begin{abstract}
A simple and efficient electrochemical method that utilizes two steel electrodes and is capable of reducing the colour of tea effluent prior to its discharge into the river system has been developed. The effects of potential difference, inter-electrode distance, surface area of electrodes to effluent volume ratio (S/V), effluent $\mathrm{pH}$, temperature and effluent dilution on power consumption, were investigated. This method was effective at a potential difference of 24 volts, inter-electrode distance of $5 \mathrm{~mm}, \mathrm{~S} / \mathrm{V}$ of $18.2 \mathrm{~m}^{2} / \mathrm{m}^{3}$ and effluent $\mathrm{pH}$ of 6 . Effluent dilution led to increase in power consumption while raising temperatures led to a reduction in power consumption. Electrochemical method reduced COD, BOD and electrical conductivity by $96.6 \%, 84.0 \%$ and $31.5 \%$ respectively but increased $\mathrm{pH}$ by $10.32 \%$. The final $\mathrm{pH}, \mathrm{EC}, \mathrm{COD}$ and BOD values were below KBS maximum contaminant levels. The proposed mechanism in colour removal process was phenol coupling. Phenolic tea colour pigments were oxidized by electrons from ionization of iron to form keto radicals, which polymerized to form a long chain polymer. The polymer was electro-floated to the surface by hydrogen gas generated from the reduction of water and oxidation of theaflavins.
\end{abstract}

KEY WORDS: Tea effluent, Electrochemical, Phenol coupling, Radicals, Colour removal, Theaflavins

\section{INTRODUCTION}

Chemomi tea factory (CTF) was established in 1950's and produces several tea grades for the export market. Since then, the factory has expanded its production over the years to meet the demand in export and now produces 6,600 tonnes per annum [1]. This has led to doubling in water usage during the factory cleaning procedures, hence large volumes of effluent wastewater are discharged per day (from $10 \mathrm{~m}^{3}$ to $20 \mathrm{~m}^{3}$ ). At the present the biological wastewater treatment facility is unable to remove colour from the tea effluent and this has been a major issue in the whole tea industry, i.e. not only the Chemomi tea factory in Kenya.

Colour pigments are formed during the processing of black tea when it is discharged into the treatment system with a colour index of 2,004 Pt-Co colour units [2]. This colour level is higher than local and international standards [3]. At the entry point to the treatment system the effluent has low colour which intensifies at the discharge point into river Mokong, a tributary of River Yala to 9,210 Pt-Co colour units. This implies that the biological treatment process is not helpful in reducing the effluent colour [4].

All industries in Kenya are required to collect, treat and dispose safely all the wastes that are generated within their areas of jurisdiction [5]. Every industry is required to maintain sanitary conditions or prevent the occurrence therein of any conditions liable to be injurious or dangerous to public health [6]. The release of noxious substances into water resources is also prohibited. The Environmental Management and Co-ordination Act, [7] has bestowed every one living in Kenya with the responsibility to create and protect a healthy environment.

There is great concern from the public, Eastern Produce Kenya Ltd (EPK) and Lake Victoria Environmental Management Programme (LVEMP) for the deterioration of quality rivers' water discharging into Lake Victoria. Communities living along River Yala have registered their

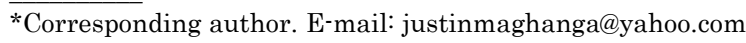


concern to the deteriorating water quality and the source of pollution has been suspected to be the tea factory effluent that discharges into the river. The effluent has varying content of theaflavins [8], a product of black tea manufacture, responsible for colour and perhaps the main effluent culprit.

Coagulation and flocculation are traditional methods for the treatment of polluted water. In these processes, coagulating agents such as alum or ferric chloride and other additives such as polyelectrolytes are dosed to produce larger aggregates, which can be separated physically. This is a multi-stage process that requires considerable land area and a continual supply of chemicals [9]. Solution $\mathrm{pH}$ determines the speciation of metal ions. Thus, solution $\mathrm{pH}$ influences the overall efficiency and effectiveness of electrocoagulation.

The electrochemical method is a simple and efficient method for the treatment of water and many kinds of wastewater. This process is highly dependent on the chemistry of the wastewater, especially its conductivity. The insoluble metal hydroxides of iron can remove pollutants by surface complexation or electrostatic attraction. The prehydrolysis of $\mathrm{Fe}^{3+}$ cations also leads to the formation of reactive clusters for wastewater treatment [10]. Electrochemical method was effective in removal of colour from Kraft mill effluent in paper industry in Kenya [11]. The method has been tested successfully in the separation of pollutants from restaurant wastewater [12], treatment of urban wastewater [13], degradation and decolourization of dye solution [14, 15], defluoridation of water [16], removal of nitrate, sulfide and sulfate from water [17], decolourization of Kraft pulp and paper mill effluent [18].

The main colour pigments in the tea effluent are flavanols. Theaflavins (Figure 1) are reddish-orange pigment that have conjugated aromatic ring, the same chain found in the paper and kraft mill chromophores. In view of this, it was necessary to develop and optimize an effective electrochemical method for colour removal using a two-electrode system.

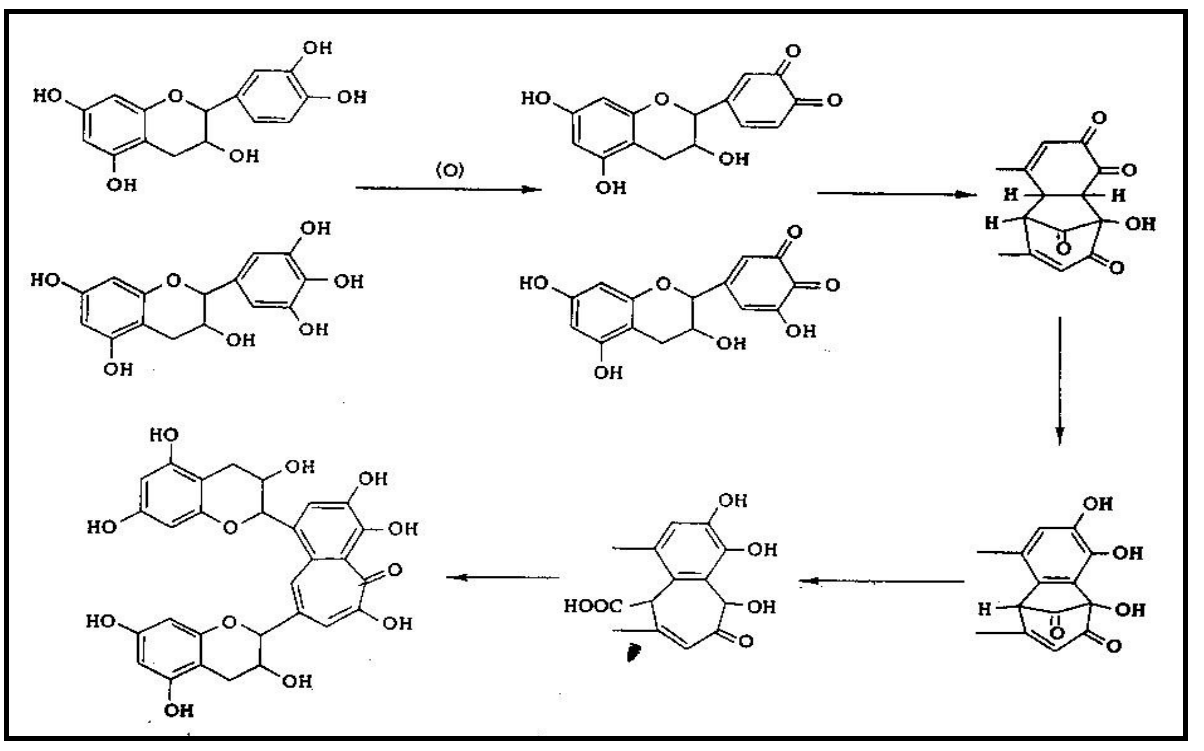

Figure 1. Formation of theaflavins from simple catechins [8]. 


\section{Sampling}

\section{EXPERIMENTAL}

Four sampling sites were established along the constructed wetlands which include: discharge from gravel bed hyponomics, GBH (SP1), discharge of the surface cell 1, SC1 (SP2), discharge of the surface cell 2, SC2 (SP3), discharge of the surface cell 3, SC3 (SP4). Figure 2 shows the selected sampling points within the Chemomi constructed wetlands plant. Samples from SP1 and SP4 were used in electrochemical experiments, and variations in potential difference, electrode spacing, effluent $\mathrm{pH}$, electrode surface area to effluent volume ratio, effluent temperature and effluent dilution measured.

Samples were obtained and transported to the laboratory using insulated icebox and then preserved below $4{ }^{0} \mathrm{C}$ to avoid any biological degradation before analysis [19]. Parameters that were measured for the raw and treated effluent included $\mathrm{pH}$, electrical conductivity, colour, dissolved oxygen (DO), biochemical oxygen demand (BOD) and chemical oxygen demand (COD) as per the standard procedures [19].

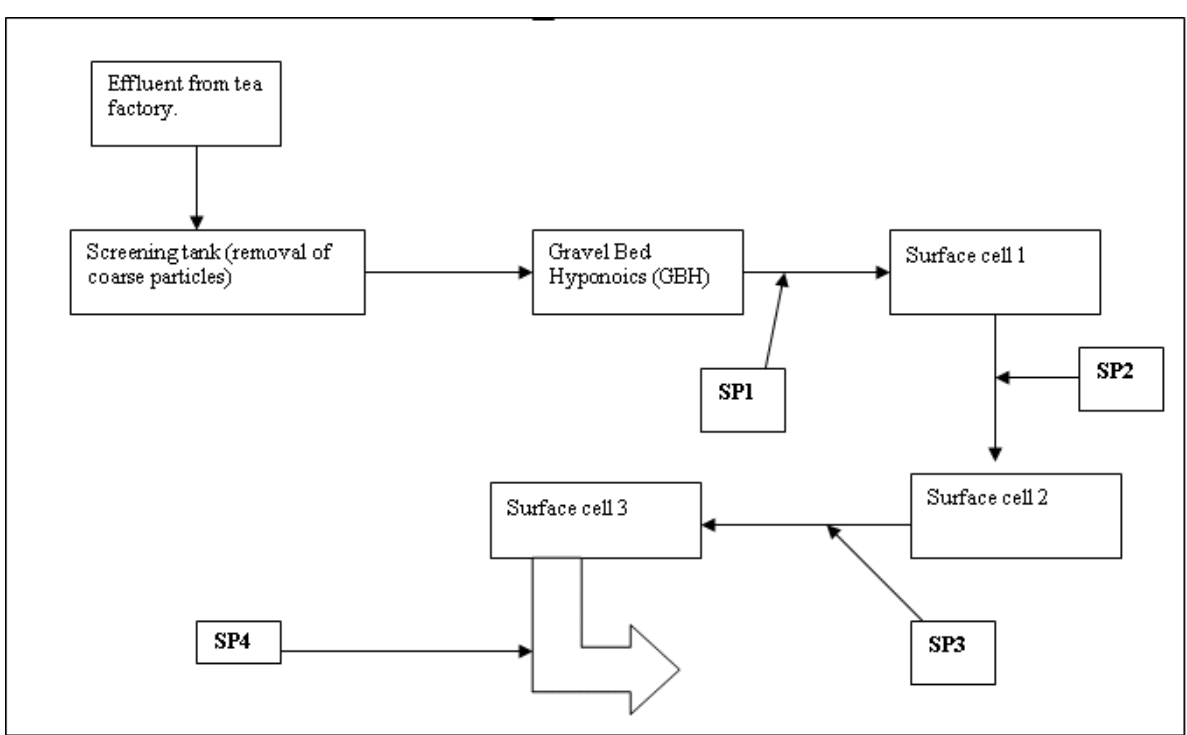

Figure 2. Sampling points in Chemomi constructed wetland system, SP1-SP4.

\section{Reagents and chemicals}

These included; sulfuric acid, sodium hydroxide, $\mathrm{pH}$ buffer solution 4.0 and 7.0, phosphate buffer, magnesium sulfate, calcium chloride, ferric chloride, potassium dichromate, mercury sulfate, silver sulfate, 1,10-phenanthroline monohydrate, ferrous ammonium sulfate, ferrous sulfate, salicylic acid, potassium nitrate, hydrated iron(II) sulfate and nitric acid. All chemicals were of analytical grade (Fischer Scientific, UK).

\section{Apparatus and measurements}

The equipments used were an AC-DC voltage power supply (Ray Equipment and Engineering, UK), Electronic shaker (Unimax 1010 DT, Germany), pH meter (HANNA 211, Italy), Conductivity meter (HANNA EC 215, Italy), DR 2010 dataloging spectrophotometer (HACH, USA). 
A sketch of the set up for the electrochemical measurements is shown in Figure 3. The effluent $(400 \mathrm{~mL})$ drawn from SP1-SP4 was placed in a $500 \mathrm{~mL}$ beaker. Two steel plate electrodes, $137.5 \mathrm{~mm}$ height by $3.13 \mathrm{~mm}$ thickness by $50 \mathrm{~mm}$ width were used as both anode and cathode and suspended above the beaker and into the sample. The electrodes were separated using an insulating material to maintain the desired electrode spacing. Power was supplied by an AC to DC variable power supply unit and a variable rheostat and ammeter were connected in series. Shaking of sample was done by an electrical shaker at $100 \mathrm{rev} / \mathrm{min}$ to maintain uniform shaking. The power and timer were switched on simultaneously and the current passing through was noted. Once the flocs started to form, power was switched off, the timer stopped and the time taken to form flocs was recorded. Power consumption was calculated using the relationship; Power $($ watt-h) $=$ current $(A)$ x potential difference $(V) \times$ time $(\mathrm{h})$ as shown in Equation 1.

$$
\mathrm{P}=\mathrm{I} \text { V T }
$$

After each run, the electrodes were rinsed in $8 \%$ sulfuric acid to avoid electrode fouling and passivation.

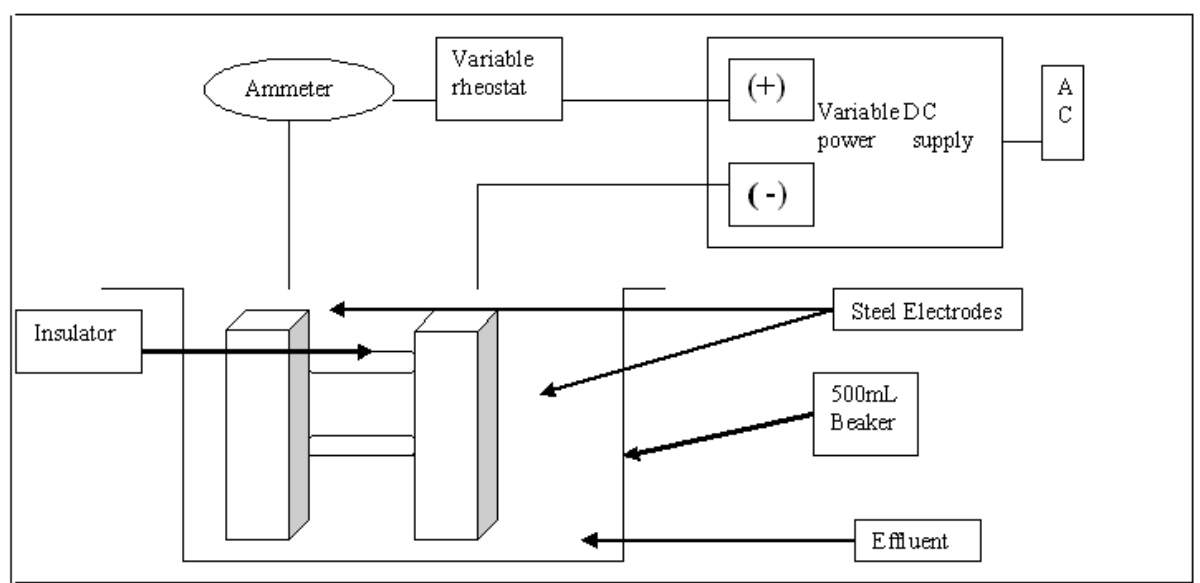

Figure 3. Set up for the electrochemical measurements.

\section{Process optimization}

Variation of electrochemical parameters. The current passed and the time taken to form flocs was recorded for both raw and treated effluents under the following conditions:

Potential difference. This was varied to either 12 volts or 24 volts dc using the variable power supply unit.

Surface area of electrodes to effluent volume ratio $(S / V)$. This was altered by varying the depth of the electrodes which corresponded to S/V of 13.0, 15.6, 18.2 and $19.5 \mathrm{~m}^{2} / \mathrm{m}^{3}$, respectively. Electrolysis was carried out at 24 volts.

Inter-electrode spacing. The steel electrodes were used at different spacing of 2, 5, 7 and 10 $\mathrm{mm}$. Electrolysis was carried out at 24 volts at optimised $\mathrm{S} / \mathrm{V}$ of $18.2 \mathrm{~m}^{2} / \mathrm{m}^{3}$. 
Effluent $\mathrm{pH}$. The $\mathrm{pH}$ was adjusted to $\mathrm{pH} 4.0,5.0,6.0$ and 7.0 using either $1 \mathrm{M} \mathrm{H}_{2} \mathrm{SO}_{4}$ or $1 \mathrm{M}$ $\mathrm{NaOH}$. Electrochemical reaction was carried at 24 volts dc, $5 \mathrm{~mm}$ inter-electrode spacing and $\mathrm{S} / \mathrm{V}$ of $18.2 \mathrm{~m}^{2} / \mathrm{m}^{3}$.

Effluent temperature. This was adjusted to $20,25,30$ and $35{ }^{\circ} \mathrm{C}$ using a thermo-stated hot plate. Electrochemical reaction was carried at 24 volts dc, $5 \mathrm{~mm}$ inter-electrode spacing and $\mathrm{S} / \mathrm{V}$ of $18.2 \mathrm{~m}^{2} / \mathrm{m}^{3}$.

Effluent dilution. A volume of 400, 320, 280 and $240 \mathrm{~mL}$ of raw and treated effluent were each separately measured and put in a volumetric flask. A volume of $0,80,120$ and $160 \mathrm{~mL}$ of distilled water was then added to each flask, respectively, to make a total of $400 \mathrm{~mL}$. The mixture was shaken and transferred to a $500 \mathrm{~mL}$ beaker. This gave a dilution of $0,20,30$ and 40 $\% \mathrm{v} / \mathrm{v}$, respectively. Electrochemical reaction was carried at 24 volts dc, $5 \mathrm{~mm}$ inter-electrode spacing and $\mathrm{S} / \mathrm{V}$ of $18.2 \mathrm{~m}^{2} / \mathrm{m}^{3}$.

\section{RESULTS AND DISCUSSION}

Colour and dissolved oxygen levels of tea effluent in the constructed wetlands

The results of colour and dissolved oxygen levels of tea effluent in the constructed wetlands are presented in Table 1. Colour intensity increased as the effluent moved down the treatment system, hence the discharged effluent to river Mokong had more colour than the raw effluent. The increase in colour was attributed to the formation of organic compounds down the treatment system due to oxidation as effluent cascaded from the SP1 to SP4. In the formation of theaflavins from catechins oxygen is required [8]. Table 1 indicates that dissolved oxygen was taken up from the effluent and there was a net reduction of $64 \%$ from SP1 to SP4.

Table 1. Colour and dissolved oxygen of tea effluent in the constructed wetlands.

\begin{tabular}{|l|c|c|}
\hline Effluent type & Colour, mg/L Pt-Co units & Dissolved oxygen, mg/L \\
\hline SP 1 & 2,004 & 2.37 \\
\hline SP 2 & 2,265 & 1.51 \\
\hline SP 3 & 7,370 & 1.05 \\
\hline SP 4 & 9,210 & 0.84 \\
\hline
\end{tabular}

Effect of potential difference on power consumption

The results of power consumption at 12 and 24 volts are presented in Figure 4 . There was significant difference in power consumption between the effluent type and potential difference applied while the interaction of effluent type and potential difference was not significantly different. The mean power consumption for treated effluent was higher than that of the raw effluent and was significantly different (LSD $=0.03$ ).

A potential difference of 24 volts gave lower mean power consumption during colour removal process. At both 12 and 24 volts, power consumption was lower in the raw. Applying 24 volts, led to lower power consumption for colour removal from both raw and treated effluent as compared to 12 volts. The low power consumption could be attributed to the low content of the tea colour pigments in the raw effluent. The catechins continue to undergo oxidation and colour level is low until the SP4 where there is complete oxidation and the intensity of the colour rises (Table 1). The formation of more conjugated phenols makes the process of colour removal in the treated effluent slower as compared to the raw effluent. 


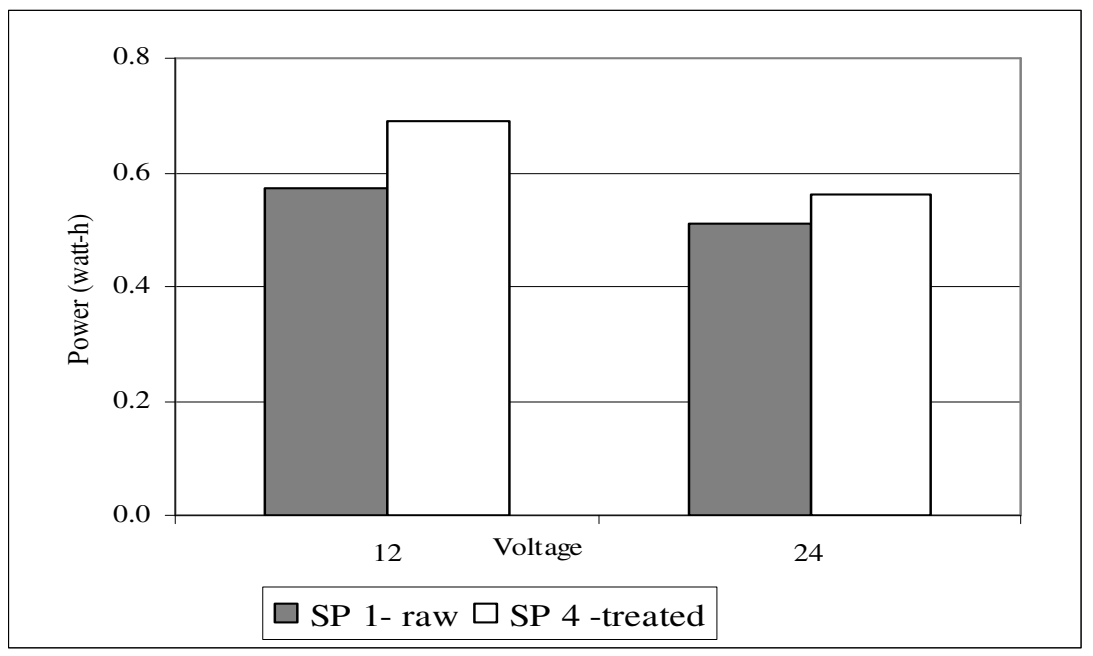

Figure 4. Power consumption (watt-h) at 12 and 24 volts of raw and treated effluent.

\section{Effect of inter-electrode distance on power consumption}

The results of inter-electrode distance on power consumption are presented in Figure 5. The interaction between the effluent type and spacing was highly significant $(p<0.01)$ in power consumption. Inter-electrode spacing and effluent type were significantly different in power consumption. Raw effluent had lower group mean power consumption than the treated effluent. Inter-electrode spacing of $5 \mathrm{~mm}$ had the lowest group mean power consumption.

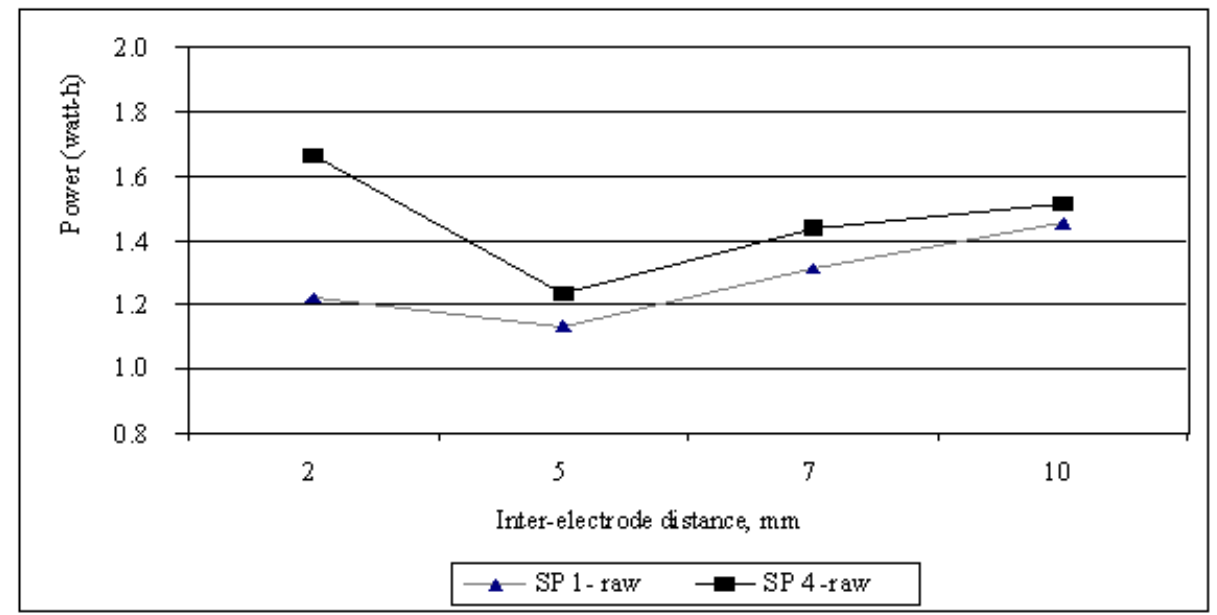

Figure 5. Effect of inter-electrode distance on power consumption (watt-h).

There was a decrease in power consumption in the cell as the inter-electrode distance increased from $2 \mathrm{~mm}$ to $5 \mathrm{~mm}$ and an increase when the inter-electrode distance was increased from $7 \mathrm{~mm}$ to $10 \mathrm{~mm}$ in the raw effluent (Figure 5). A similar trend was seen in the treated 
effluent and this was attributed to the high current flowing through the system as electrodes almost provided complete circuit at $2 \mathrm{~mm}$ spacing. The results indicated that less power was required to remove colour from the raw than the treated effluent. At $5 \mathrm{~mm}$ spacing, both raw and treated effluent had the lowest power consumption. This inter-electrode spacing was hence chosen as optimum for subsequent colour removal experiments.

Effect of effluent surface area to volume ratio, $S / V\left(\mathrm{~m}^{2} / \mathrm{m}^{3}\right)$ on power consumption

There was no significant difference in power consumption in the type of effluent; however the interaction of $\mathrm{S} / \mathrm{V}$ and effluent type was highly significant $(\mathrm{p}<0.02)$. Raw effluent had a lower group mean power consumption of 1.30 watt-h compared to 1.32 watt-h in the treated effluent. There was significant difference in power consumption when $\mathrm{S} / \mathrm{V}$ was varied between 13.0 to $19.5 \mathrm{~m}^{2} / \mathrm{m}^{3}$. An $\mathrm{S} / \mathrm{V}$ of $18.2 \mathrm{~m}^{2} / \mathrm{m}^{3}$ had lower group mean power consumption as compared to $13.0 \mathrm{~m}^{2} / \mathrm{m}^{3}$ which had the highest (Figure 6). The decrease in power consumption was quite sharp in the raw than the treated effluent. Increase in release of $\mathrm{Fe}^{2+}$ ions hastened coagulation process hence, colour removal at $\mathrm{S} / \mathrm{V}$ of $18.2 \mathrm{~m}^{2} / \mathrm{m}^{3}$ was more effective than at $13.0 \mathrm{~m}^{2} / \mathrm{m}^{3}$. Increasing the $\mathrm{S} / \mathrm{V}$ to $19.5 \mathrm{~m}^{2} / \mathrm{m}^{3}$, slowed down formation of $\mathrm{Fe}^{2+}$ ions probably due to a reduction in current density eventually leading to high power consumption.

The optimum S/V for colour removal was $18.2 \mathrm{~m}^{2} / \mathrm{m}^{3}$, a potential difference of 24 volts and $5 \mathrm{~mm}$ inter-electrode spacing. This ratio was comparable with $18.8 \mathrm{~m}^{2} / \mathrm{m}^{3}$, which was obtained by Osipenko in 1977 [20].

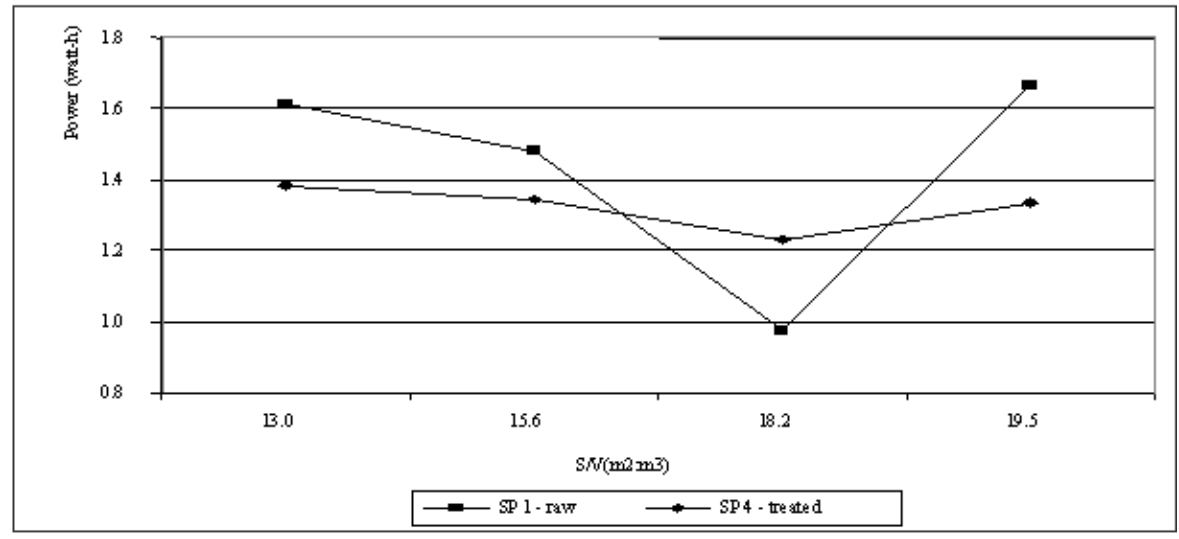

Figure 6. Effect of S/V on power consumption (watt-h) at 24 volts and $5 \mathrm{~mm}$ electrode spacing.

\section{Effect of effluent $\mathrm{pH}$ on power consumption}

The effect of effluent $\mathrm{pH}$ on power consumption is illustrated in Figure 7. Variation of $\mathrm{pH}$, effluent type and interaction between effluent types had significant difference in power consumption. The type of effluent was significantly different in power consumption (LSD = 0.16). Mean power consumption was lowest in raw effluent and the highest in treated effluent. Lowering the $\mathrm{pH}$ to 4 led to the highest mean power consumption. The lowering of the $\mathrm{pH}$ further led to suitable conditions for ionization of wastewater and oxidation of iron to $\mathrm{Fe}^{2+}$ ions hence high power consumption (Figure 7). The optimum $\mathrm{pH}$ with the lowest power consumption was $\mathrm{pH} 6$, which was closer to the initial effluent $\mathrm{pH}$ and also suitable for the stability of $\mathrm{Fe}^{3+}$ ions. 


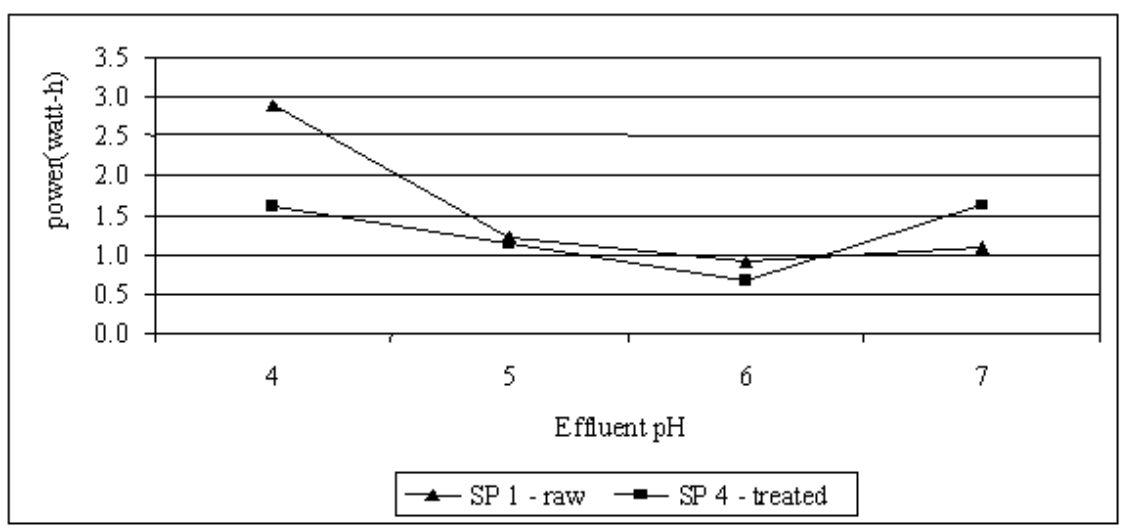

Figure 7. Effect of effluent $\mathrm{pH}$ on power consumption (watt-h).

\section{Effect of effluent temperature on power consumption}

The interaction between effluent type and temperatures was highly significant $(\mathrm{p}<0.01)$. Effluent temperatures were significantly different in power consumption, with $35^{\circ} \mathrm{C}$ having the lowest power consumption. Power consumption decreased with increase in temperatures from 20 to $35{ }^{\circ} \mathrm{C}$ (Figure 8 ). At higher temperatures, molecules gain kinetic energy and collisions between molecules are increased.

This enhances the production of $\mathrm{Fe}^{2+}$ ions at the anode. These findings agree with the results of Springer et al. [21] stating that high temperatures favors colour removal which leads to low power consumption [21].

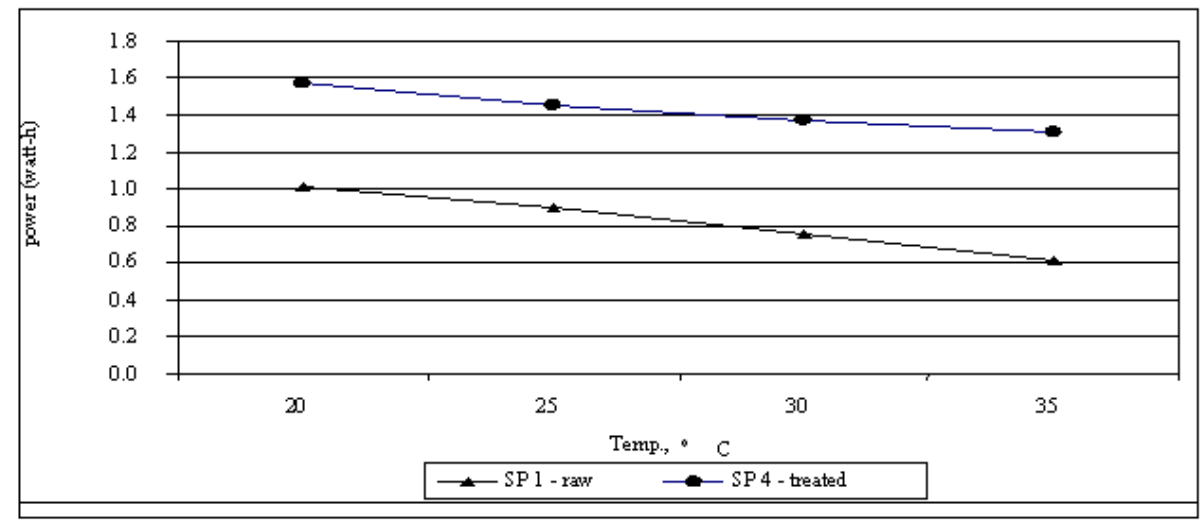

Figure 8. Effect of effluent temperature on power consumption (watt-h).

\section{Effect of effluent dilution on power consumption}

The effluent type and dilution level had significant effect in power consumption. The effect of the interaction between the effluent type and level of dilution was highly significant $(\mathrm{p}<0.01)$. Mean power consumption was higher in treated effluent than in raw effluent, hence if diluted, 
treated effluent requires less power consumption. Power consumption was significantly different when effluent was diluted to $20 \%$ and $40 \% \mathrm{v} / \mathrm{v}$. Undiluted effluent had the lowest mean power consumption than all diluted samples. The high power consumption in diluted samples could be attributed to a reduction in electrical conductivity leading to relatively low current. In both effluents, the highest power consumption was recorded at the highest dilution which had the lowest electrical conductivity.

Diluting the effluent led to increased power consumption (Figure 9). This was caused by the reduction in electrical conductivity of effluent. The rate of formation of $\mathrm{Fe}^{2+}$ ions was reduced probably due to a lower current density. A similar trend was observed in the treated effluent. However, diluting the treated effluent had the highest effect on power consumption as compared to the raw effluent.

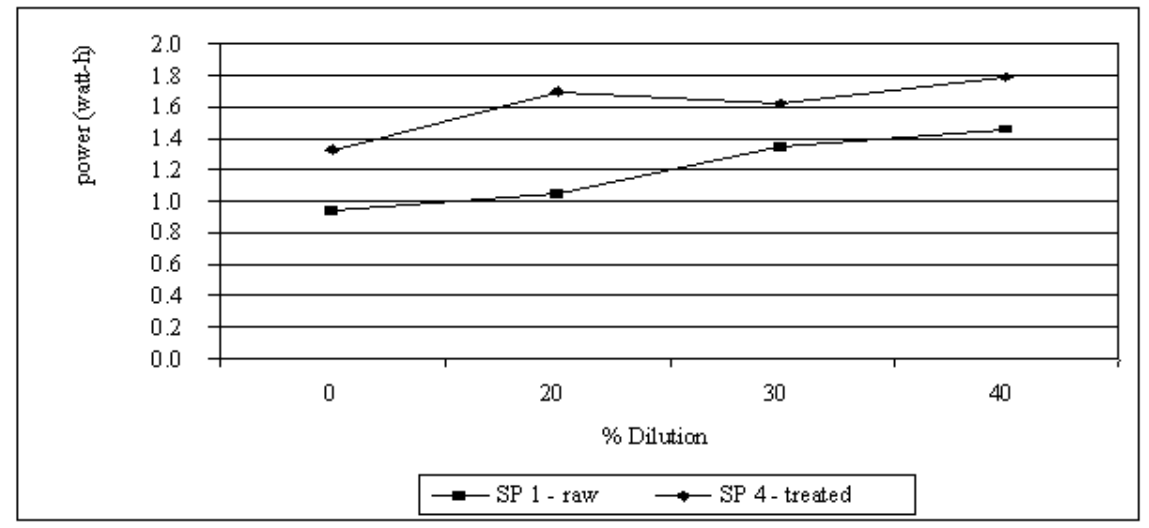

Figure 9. Effect of effluent dilution on power consumption (watt-h).

\section{Effect of electrochemical colour removal on effluent parameters}

Effluent from the four sampling points was clarified by electrochemical method using the optimized conditions of 24 volts potential difference, $5 \mathrm{~mm}$ inter-electrode spacing and S/V of $18.2 \mathrm{~m}^{2} / \mathrm{m}^{3}$ with no dilution. Electrochemical method had the effect of reducing the tea treated effluent parameters as seen in Table 2 . There was a $100 \%$ colour removal in all the samples from SP1 to SP4.

Table 2. Physico-chemical analysis of raw and electrochemically clarified (EC) tea effluent.

\begin{tabular}{|c|c|c|c|c|c|c|c|c|c|c|}
\hline \multirow{2}{*}{ Sample } & \multicolumn{2}{|c|}{$\mathrm{pH}$} & \multicolumn{2}{c|}{ Colour, Pt-Co units } & \multicolumn{2}{c|}{ EC $\mu$ S/cm } & \multicolumn{2}{c|}{ COD, mg/L } & \multicolumn{2}{c|}{ BOD, $\mathrm{mg} / \mathrm{L}$} \\
\cline { 2 - 12 } & Raw & EC & Raw & EC & Raw & EC & Raw & EC & Raw & EC \\
\hline SP1 & 6.72 & 7.11 & 2,004 & 0 & 317 & 217 & 607.0 & 53.0 & 193.4 & 30.9 \\
\hline SP2 & 6.69 & 7.14 & 2,265 & 0 & 298 & 224 & 628.0 & 80.2 & 184.8 & 39.4 \\
\hline SP3 & 6.51 & 7.16 & 7,370 & 0 & 201 & 154 & 427.0 & 18.7 & 103.0 & 36.4 \\
\hline SP4 & 6.49 & 7.16 & 9,210 & 0 & 134 & 106 & 293.0 & 10.0 & 42.0 & 24.2 \\
\hline
\end{tabular}

The maximum COD and BOD reduction was $96.6 \%$ and $84.0 \%$, respectively. The highest reduction in COD was in SP4 and lowest in SP2. However, BOD reduction was highest in SP1 and lowest in SP4. The final values of COD and BOD at the discharge in SP4 were within the acceptable limits (Table 2).

Bull. Chem. Soc. Ethiop. 2009, 23(3) 
There was a negative effect on treated effluent $\mathrm{pH}$ as it increased by $5.80 \%$ and $10.32 \%$, however the values were within acceptable range. Electrical conductivity was reduced by between $20.9 \%$ and $31.5 \%$ with the highest reduction at SP1. In all sampling points conductivity values were within acceptable ranges (Table 2 ).

\section{Comparison of electrochemical colour removal in tea and paper mill effluent in Kenya}

The power needed for total colour removal in raw effluent is lower than that needed in treated effluent (Table 3). In comparison with the paper mill effluent, alum had a higher power requirement than that of teaeffluent. However, power requirement using wood ash and phosphate rock in paper mill effluent was lower as compared to electrochemical method alone in tea effluent. It is therefore suggested that further study be carried out to make this method economical by looking for alternative electrolytes to reduce power consumption.

Table 3. Comparison of power needed per cubic meter in tea versus paper mill effluent in Kenya [18].

\begin{tabular}{|l|c|c|}
\hline Effluent type & Power consumption per $\mathrm{m}^{3}(\mathrm{Wh})$ & Power consumption per day (MWh) \\
\hline SP1 - tea raw effluent & 2,270 & 40.05 \\
\hline SP4 - tea treated effluent & 2,755 & 49.95 \\
\hline Paper mill effluent with alum & 3,139 & 116.42 \\
\hline Paper mill effluent with phosphate rock & 1,167 & 40.85 \\
\hline Paper mill effluent with wood ash & 1,200 & 42.00 \\
\hline
\end{tabular}

Proposed mechanism of colour removal from tea effluent

Electrons lost during dissolution of $\mathrm{Fe}$ to $\mathrm{Fe}^{2+}$ and $\mathrm{Fe}^{3+}$ (equation 2) at the anode attack and remove hydrogen from the hydroxyl $(-\mathrm{OH})$ of the phenol, leading to the formation of a radical at the oxygen of the Ar-C-O.

$$
\mathrm{Fe}(\mathrm{s}) \rightarrow \mathrm{Fe}^{2+}+2 \mathrm{e}^{-} \rightarrow \mathrm{Fe}^{3+}+\mathrm{e}^{-}(\mathrm{aq})
$$

The radical is very reactive hence unstable. One electron is donated from the double bond in the aromatic ring leaving a radical at the $\mathrm{C}$ in the ring. Several of the radicals formed in the $\mathrm{C}$ ring donate an electron each to form a pair of electrons leading to a polymer which is suspended in the surface by hydrogen gas released from the electrolysis of effluent and from the theaflavins as shown in equation 3 .

$$
2 \mathrm{H}^{+}+2 \mathrm{e}^{-} \quad \rightarrow_{2}(\mathrm{~g})
$$

These processes explain the increase in clarified effluent $\mathrm{pH}$ in all the effluent types as seen in Table 2.

The proposed mechanism of colour removal from the tea effluent was phenol coupling resulting from radicals. The radicals were formed after removal of hydrogen from the $\mathrm{OH}$ attached to the aromatic ring by electrons lost during dissolution of iron and from the aqueous solution (equation 2).

\section{CONCLUSIONS}

In conclusion, the findings indicate that electrochemical colour removal method using steel electrodes was more effective in the raw effluent than the treated effluent. The optimised conditions for this process were a potential difference of 24 volts, inter-electrode spacing of 5 $\mathrm{mm}$ and surface area of electrodes to volume ratio of $18.2 \mathrm{~m}^{2} / \mathrm{m}^{3}$. This study indicated that besides total colour removal, electrochemical method is effective in the reduction of COD, BOD 
and electrical conductivity while raising the effluent $\mathrm{pH}$. No further biological treatment would be needed for the effluent treatment if the Chemomi Tea Factory (and other tea factories) adopts this colour removal method because most of the physiochemical parameters of the treated effluent will fall within the NEMA standards [7]. The process can be enhanced when temperatures are above $20{ }^{\circ} \mathrm{C}$, hence electrochemical reaction can be performed during daytime when temperatures are relatively high.

\section{AKNOWLEDGEMENTS}

The authors wish to thank the Director of Eastern Produce Kenya Limited (EPK), Mr. S.L.M Hutchinson and the Technical Officer; Mr. W. Spring for allowing us to collect data from Chemomi Tea Factory constructed wetlands. We would also like to thank Moi University

Research Committee for funding this research.

\section{REFERENCES}

1. Technical Department, Eastern Produce Kenya Limited Annual Report; 2002.

2. Technical Department, Eastern Produce Kenya Limited Annual Report; 2004.

3. Kenya Bureau of Standards Guidelines for Drinking Water, Kenya Bureau of Standards: Nairobi, Kenya; 1996.

4. Archibald, F.; Roy-Arcand, L. Water Res. 1995, 29, 669.

5. GOK Water Act (Cap 372) Sec. 145-147 of the Laws of Kenya; 1972.

6. GOK Public Health Act (Cap 372) Part ix, Sec. 16 of the Laws of Kenya; 1986.

7. GOK EMC Act. Environmental Management and Coordination Act. GOK; 1999.

8. Roberts, E.A.H. Economic Importance of Flavonoid Substances: Tea Fermentation, in The Chemistry of Flavonoid Compounds, Geissman, T.A. (Ed.), Pergamon: Oxford; 1962; pp 468-512.

9. Holt, P.; Barton, G.; Mitchel, C. Electrocoagulation as a wastewater treatment, The third Annual Australian Environmental Engineering Research Event; 2006; pp 23-26.

10. Mollah, M.Y.A.; Schenah, R.; Parga, J.P.; Coke, D.L. J. Hazard. Mater. 2001, B84, 29.

11. Orori, B.O.; Eiegni, L.; Rajab, M.S. Pulp and Paper Canada 2005, 106, 21.

12. Chen, X.; Chen, G.; Yue, P.L. Separation Purification Technology 2000, 20, 921.

13. Pouet, M.F.; Grasmick, A. Water Sci. Technol. 1995, 31, 275.

14. Daneshvar, N.; Ashassi, H.; Kasiri, M.B. J. Hazard. Mater. 2004, B112, 55.

15. Shen, Z.; Wang, W.; Jia, J.; Ye, J.; Feng, X.; Peng, A. J. Hazard. Mater. 2001, B84, 107.

16. Mameri, N.; Lounici, H.; Belhonice, D.; Grib, H.; Piron, D.L.; Yahiat, Y. Separation Purification Technology 2001, 24, 113.

17. Murugananthan, M.; Bhaskar, G.; Raju, G.; Prabhakar, S. J. Hazard. Mater. 2004, B109, 37.

18. Etiégni, L.; Oricho, O.D.; Ofosu-Asiedu, K.; Senelwa, K.A.; Surtan, K.G.; Omutange, E.S. Water Sci. Technol. 2007, 55, 15.

19. American Public Health association (APHA) Standard Methods for the Examination of Water and Wastewater, 18th ed., American Public Health Association: Washington, DC; 1992.

20. Osipenko, V.D.; Porogleyi, P.I. Metallurgist 1977, 21, 44.

21. Springer, A.M.; Hand, V.C; Jarvis, T.S. Tappi Journal 1995, 78, 86. 